\title{
Flow velocity tolerance of lowland stream caddisfly larvae (Trichoptera)
}

\author{
J. H. F. de Brouwer ${ }^{1}$ (1) - A. A. Besse-Lototskaya ${ }^{1}$ C. J. F. ter Braak ${ }^{2} \cdot$ \\ M. H. S. Kraak ${ }^{3}$ P. F. M. Verdonschot ${ }^{1,3}$
}

Received: 9 February 2016/Accepted: 1 September 2016/Published online: 14 September 2016

(c) The Author(s) 2016. This article is published with open access at Springerlink.com

\begin{abstract}
The process of macroinvertebrate drift in streams is characterized by dislodgement, drift distance and subsequent return to the bottom. While dislodgement is well studied, the fate of drifting organisms is poorly understood, especially concerning Trichoptera. Therefore, the aim of the present study was to determine the ability of six case-building Trichoptera species to return to the stream bottom under different flow velocity conditions in a laboratory flume. The selected species occur in North-West European sandy lowland streams along a gradient from lentic to lotic environments. We determined species specific probability curves for both living and dead (control) specimens to return to the bottom from drift at different flow velocities and established species specific return rates. Species on the lotic end of the gradient had highest return rates at high flow velocity and used active behaviour most efficiently to return to the bottom from drift. The observed gradient of flow velocity tolerance and species specific abilities to settle from drift indicate that, in addition to dislodgement, the process of returning to the bottom is of equal importance in determining flow velocity tolerance of Trichoptera species.
\end{abstract}

J. H. F. de Brouwer

jan.debrouwer@wur.nl

1 Department of Freshwater Ecology, Alterra, Wageningen University and Research, P.O. Box 47,

6700 AA Wageningen, The Netherlands

2 Biometris, Wageningen University Research, Wageningen, The Netherlands

3 Institute for Biodiversity and Ecosystem Dynamics (IBED), University of Amsterdam, P.O. Box 94248, 1090 GE Amsterdam, The Netherlands
Keywords Trichoptera - Drift · Return rates · Flow velocity · Lowland streams

\section{Introduction}

Benthic invertebrates in streams are either sessile, move around actively, or are passively being moved around by the current. Weak stream flows may move invertebrates that live on or in the upper layer of the substratum to a limited extent, while strong flows can actually dislodge them and initiate drift (Vogel 1994). Drift is regarded as the dominant form of invertebrate movement in streams (Waters 1972; Brittain and Eikeland 1988), travelling short to long distances before returning to the stream bottom (McLay 1970; Neves 1979).

Previous studies revealed that drift densities of most species increase with increasing flow velocity (e.g. Corkum et al. 1977; Fonseca and Hart 1996; Gibbins et al. 2005, 2010). Yet, dislodgement occurs at both high and low flow velocity and can be initiated by multiple causes (e.g. reviewed in Waters 1972; Brittain and Eikeland 1988; Hart and Finelli 1999). Regardless of the cause of dislodgement, drifting invertebrates will eventually need to descend from the water column to prevent being washed out of the system. Hence, the process of drift is characterized by dislodgement, drift distance and subsequent return to the bottom (Lancaster 2008). Yet, the fate of most dislodged organisms is poorly understood (Palmer et al. 1996; Downes and Keough 1998; Lancaster 2008) and abilities of invertebrates to use behavioural moves to end drifting are scarcely documented (Lancaster et al. 2009; but see Oldmeadow et al. 2010), despite the importance of movements to colonize unexploited habitats (Rice et al. 2010). Thus for most species it remains unknown whether 
they passively return to the bottom from drift or use active behavioural moves (Poff and Ward 1991; Oldmeadow et al. 2010).

Especially for caddisfly larvae, escape from drift has been poorly documented. Therefore, the aim of this study was to quantify flow velocity thresholds at which selected case building Limnephilidae (Trichoptera), ranging from lotic to lentic species, are able to return to the stream bottom. We hypothesized that all species, being benthic invertebrates, use active behavioural moves to do so, but that drifting specimens of species from lotic environments can return to the stream bottom at higher flow velocities than species from lentic environments. To test this hypothesis, we performed experiments in a controlled laboratory environment, in which flow velocity was manipulated.

\section{Materials and methods}

\section{Test species}

The Limnephilidae are a relatively large family comprising many species with large differences in ecology and distribution, despite a high morphological similarity. Six species of Limnephilidae were selected for this experiment: Limnephilus lunatus (Curtis, 1834), Limnephilus rhombicus (Linnaeus 1758), Anabolia nervosa (Curtis 1834), Halesus radiatus (Curtis 1834), Chaetopteryx villosa (Fabricius 1798) and Micropterna sequax (McLachlan 1875). The selected species occur in North-West European sandy lowland streams along a gradient from lentic to lotic environments in the order listed above (Graf et al. 2006, 2008; Graf and Schmidt-Kloiber 2011). For a detailed description of their distribution see Verdonschot et al. (2014).

Fifth instar larvae were manually picked from sites where large populations of the respective species occur. Specimens were collected from the Warnsbornse beek, Coldenhovense beek, Seelbeek and drainage ditches (the Netherlands). Specimens were kept in an artificial rearingstream in separate compartments containing 200-300 conspecifics and a surplus of organic material (detritus, leaves, twigs and plants) on a bottom of fine gravel and sand. Food levels were kept high by adding extra leaves, detritus and wheat fragments weekly. Environmental conditions in the laboratory rearing-stream were kept constant with a water temperature of $10{ }^{\circ} \mathrm{C}$, a flow velocity range of $0.05-0.10 \mathrm{~m} / \mathrm{s}$ and a day:night light regime of $16: 8 \mathrm{~h}$.

\section{Experimental setup}

The experiments were conducted in a channel, which is part of a fully controlled recirculating laboratory flume system with adjustable flow velocity. Water is stored in a reservoir from which it is pumped through flow-homogenizing lamellae to flow through the channel before returning to the reservoir. The stream bed is comprised of sand grains glued to acrylic plates whilst the sides of the channel are smooth. All tests were conducted under controlled treatment-specific flow velocities, constant water temperature and light regime. The flow velocity treatments ranged from 0.10 to $0.85 \mathrm{~m} / \mathrm{s}$ in steps of $0.05 \mathrm{~m} / \mathrm{s}$. The mean column velocity (i.e. $0.6 \times$ flow depth) of the flow classes was continuously monitored at the centre of the channel using an electromagnetic flow meter (SENSA RC2 ADS, model V6d).

Per test run, one specimen was released in the water column at the entrance of the test section and monitored while the flow velocity was kept constant. Control experiments were performed with dead specimens. Test specimens were free to move upstream and downstream after release in the test section for a maximum of $6 \mathrm{~min}$ in each test-run (Fig. 1). Preliminary tests showed that 6 min was sufficient to ensure that specimens attached firmly and to rule out secondary dislodgements. We tested 20 different specimens (replicates) per species per flow velocity treatment. Experiments were stopped if specimens reached the lower end of the test section within the $6 \mathrm{~min}$, which were then classified as 'lost by drift'.

\section{Data analysis}

Return rate $(\mathrm{R})$ is defined by the number of specimens that returned to the bottom from drift and remained on the bottom of the test section during the $6 \mathrm{~min}$. We set the flow velocity intolerance threshold, the flow speed at which specimens cannot return to the bottom, at $\mathrm{R}=0.15$. Below $\mathrm{R}=0.15$, no more tests were performed at higher flow velocities for that respective species. After each run, the test specimen was killed in ethanol and the measurement repeated with the dead specimen in order to perform the control measurement.

Bayesian P-splines (see Supplementary appendix) and credible intervals were derived from the return rates $(n=20)$ at each of the tested flow velocity treatments per species for both living and dead (control) animals. The Bayesian P-splines are S-shaped probability curves calculated by a regression through the observations and illustrate species-specific tolerance for flow velocity. The probability curves consist of five phases: the flow velocity tolerance range $(\mathrm{R}: 1.00-0.85)$, the tolerance threshold $(\mathrm{R}=0.85)$, the exponential phase of decreasing return to the bottom (poor tolerance, R: 0.85-0.15), the intolerance threshold $(\mathrm{R}=0.15)$ and the intolerance range ( $\mathrm{R}: 0.15-0.00)$ (Fig. 2). 


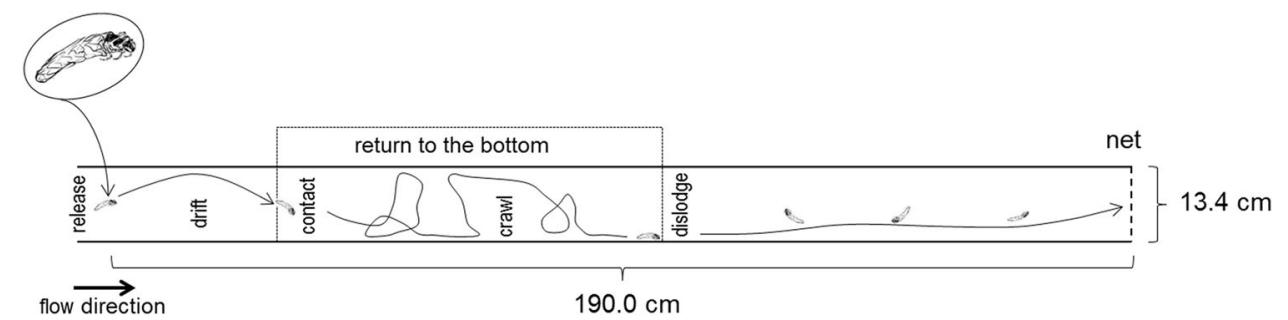

Fig. 1 Schematic overview of the experimental setup with the laboratory flume viewed from above. Specimens were released in drift at the upstream end (left in the figure). They can return to the

\section{Results}

The probability curves showed that each species has a specific tolerance for flow velocity (Fig. 3). The species can be ordered along a range based on their tolerance threshold $(\mathrm{R}>0.85)$ for flow velocity from low to high tolerance: $H$. radiatus, L. lunatus, A. nervosa, L. rhombicus, C. villosa, M. sequax. Based on the slope of the range of poor tolerance, species can be ordered differently: $L$. lunatus, A. nervosa, L. rhombicus, H. radiatus, C. villosa, M. sequax. Further, the species were ranked in this order (Fig. 3) based on their intolerance threshold ( $\mathrm{R}>0.15)$.

The return rate $(\mathrm{R})>0.85$ was similar for live and dead specimens (Fig. 4). For L. lunatus and L. rhombicus, there was no difference between the intolerance thresholds $(\mathrm{R}=0.15)$ of live and dead specimens. The intolerance threshold of dead A. nervosa was even higher than that of live specimens. The other three species had higher living intolerance threshold than the dead ones.

Comparison of the species specific ranges of tolerance of living and dead individuals in one figure (Fig. 5) clearly shows that behavioural movements of $H$. radiatus, $C$.

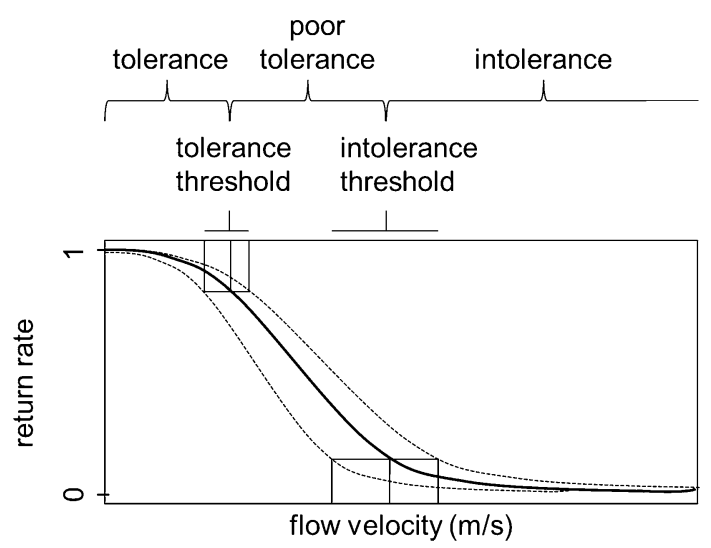

Fig. 2 Hypothetical example of a probability curve (P-spline) that shows the decreasing ability of a species to return to the bottom from drift. In the probability curve, the tolerance range $(\mathrm{R}>0.85)$, the tolerance threshold $(R=0.85)$, poor tolerance $(0.85>R>0.15)$, the intolerance threshold $(\mathrm{R}=0.15)$ and the intolerance range $(\mathrm{R}<0.15)$ are indicated bottom and settle out on the bed (first arrow point), crawl over the bottom (grey area) or may be dislodged again (second arrow in the right)

villosa and M. sequax were efficient, strongly enlarging the flow velocity tolerance of these species.

\section{Discussion}

Lowland streams are multi-stressed environments in which each stressor can be limiting for a species to survive (Corkum 1992; Allan and Johnson 1997; Brosse et al. 2003; Weigel 2003; Ormerod et al. 2010). Hydromorphology, nevertheless, is considered a main stressor to determine macroinvertebrate community composition in European lowland streams (Hering et al. 2006; Feld and Hering, 2007). It is challenging, though, to separate effects of flow velocities from other disturbances, especially sediment transport and altered habitat structure, since both factors interact (Hynes 1970).

Trichoptera have a high diversity of traits and strategies, they occur in all European ecoregions and in all types of water bodies (Conti et al. 2014). More specifically, within the family of Limnephilidae, the different species occur along a wide range of flow velocities (Mérigoux and Dolédec 2004; Dolédec et al. 2007; Sagnes et al. 2008; Mérigoux et al. 2009). This difference is also reflected by their drift numbers under different flow conditions (Gibbins et al. 2005, 2010). Similar to other species groups (Ephemeroptera: Ciborowski et al. 1977; Gibbins et al. 2005, 2010; Simuliidae: Fonseca and Hart 1996), the numbers of drifting trichopterans increase with increasing flow velocity (Verdonschot et al. 2012). But besides dislodgement, the process of drift is also characterized by drift distance and subsequent return to the bottom. Therefore in the present study, we tested whether increasing flow velocity also affected the ability of species to return to the stream bottom.

We selected five out of six species that Verdonschot et al. (2012) tested and showed that the number of specimens able to return to the stream bottom from drift decreases with increasing flow velocity, and that only the three truly lotic species showed successful active 'returning' behaviour, such as by crawling and attaching. The 
presently documented flow velocity tolerances also are consistent with the test species' classifications based on current preference and longitudinal zonation (Verdonschot et al. 2014). Even though all species occur in slow flowing streams $(0.2-0.3 \mathrm{~m} / \mathrm{s})$, only $H$. radiatus, $C$. villos $a$ and $M$. sequax are restricted to (slow) running waters, while $L$. lunatus, L. rhombicus and A. nervosa also frequently populate littoral habitats, in pools, lakes and bogs, and are considered more limnophilous (Graf et al. 2006, 2008; Graf and Schmidt-Kloiber 2011; Waringer and Graf 2011). The latter authors also indicate that M. sequax and C. villosa are often found in springs and spring brooks and have more affinity with flow than $H$. radiatus.

The tolerance threshold of $0.16-0.21 \mathrm{~m} / \mathrm{s}$ we determined for drifting specimens to return to the bottom overlaps the flow velocity range that Schnauder et al. (2010) reported to dislodge $A$. nervosa $(0.125-0.193 \mathrm{~m} / \mathrm{s})$. The authors further noted the species struggling to keep the case in position at high flow velocity while remaining on the stream bed. Likewise, our results showed that live specimens of $A$. nervosa could not actively influence the return rate and did not benefit from active behaviour.

The role of active movements in return rates from drift is poorly documented as opposed to active resistance to dislodgement. Some studies showed that Limnephilidae species offered active resistance to dislodgement (Otto 1976; Waringer 1989), while studies that included many species have observed a wide range of critical flow velocities for dislodgement (Statzner et al. 1988; Schnauder et al. 2010). In the current study, we showed that
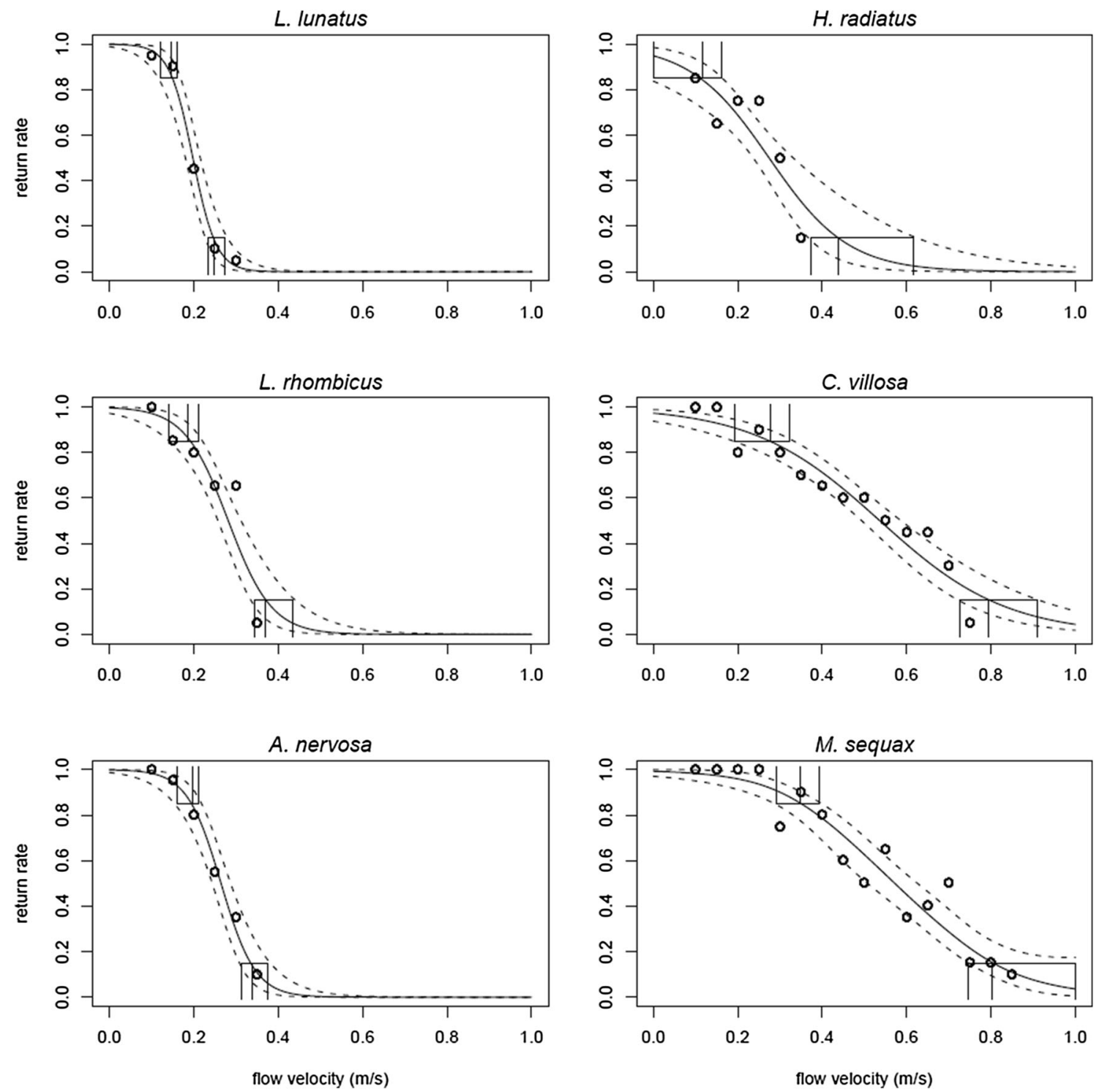

Fig. 3 Probability curves (P-splines) of living Trichoptera larvae to return to the stream bottom from drift at different flow velocities. Each figure shows the species specific mean tolerance threshold and intolerance threshold (in $\mathrm{m} / \mathrm{s}$ ) including credible intervals of active specimens 

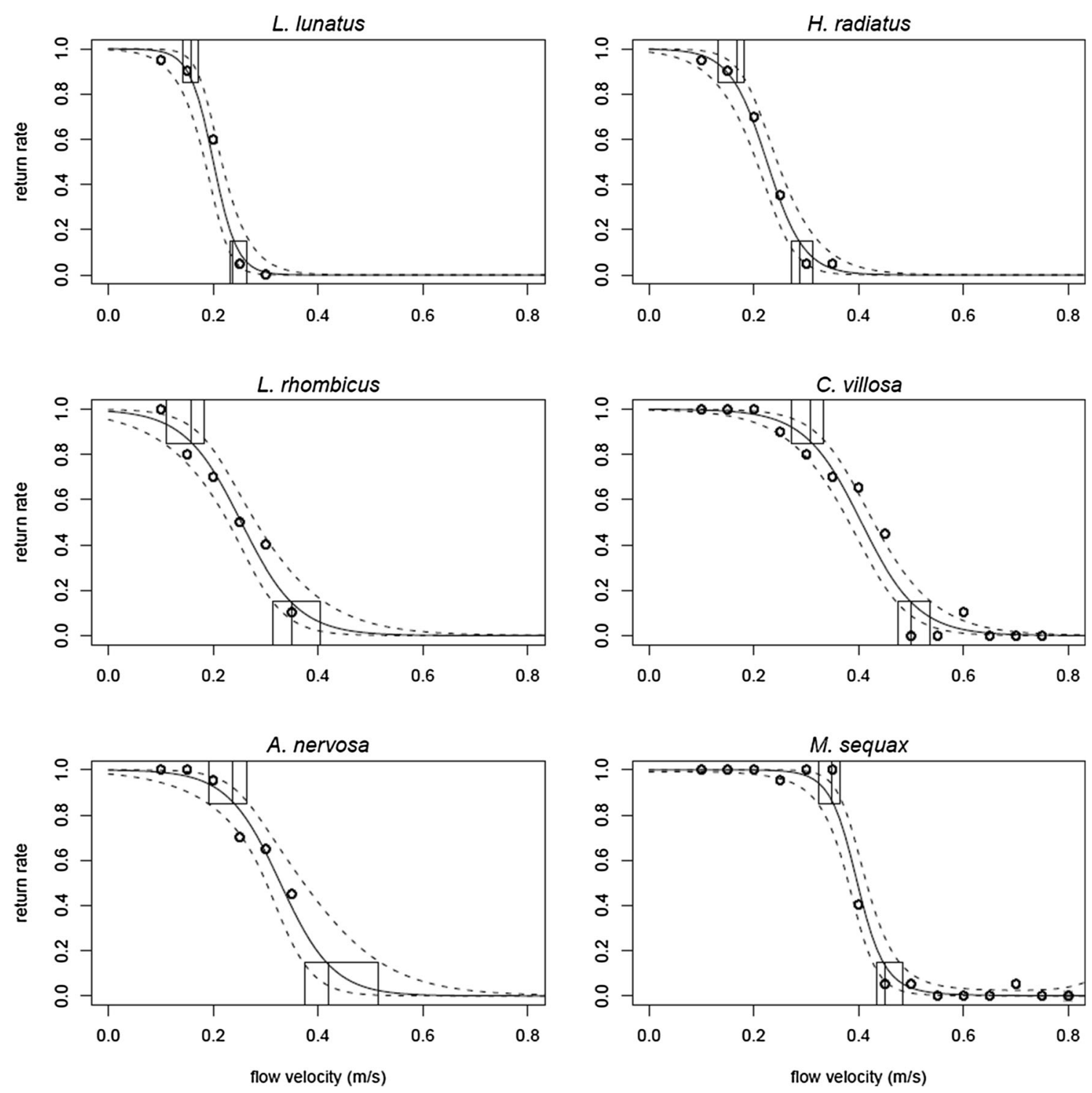

Fig. 4 Probability curves (P-splines) of dead (control) Trichoptera larvae to return to the stream bottom from drift at different flow velocities. Each figure shows the species-specific mean tolerance threshold and intolerance threshold (in $\mathrm{m} / \mathrm{s}$ ) including credible intervals of specimens

flow velocity dependent return rates of Trichoptera were species specific, both for live and dead specimens. The latter observation indicates that case properties influence return rates. The underlying cause and mechanism for the observed differences of flow tolerance between species requires further study, including case properties and/or behavioural tactics. The importance of active behaviour is indicated by the present observation that only three species exhibiting high flow velocity tolerance showed additional active behaviour to return to the bottom, such as trough crawling and attaching.

Most studies that focussed on escaping drift tested species of the order Ephemeroptera. Poff and Ward (1991), for example, showed that some species could not control drift as numbers fluctuated directly with flow velocity (e.g.
Paraleptophlebia heteronea and Ephemerella infrequens), whilst other Ephemeroptera species could (e.g. Epeorus longimanus and Baetis sp). In laboratory experiments, the number of drifting Baetis vagans increased with increasing flow velocity, opposite to Paraleptophlebia molli (Corkum et al. 1977) and both Baetis rhodani and Ecdyonurus torrentis were able to reduce drift distance by using active behaviour, with species-specific responses depending on hydrological conditions (Oldmeadow et al. 2010). The three studies mentioned above observed that Ephemeroptera that occur in lotic environments are more effective in their ability to return to the bed than species that occur in lentic environments, as observed for the Trichoptera in the current study. In contrast to Ephemeroptera larvae (Corkum et al. 1977; Poff and Ward, 
Fig. 5 Species-specific flow velocity tolerance: range of tolerance (R: $1.00-0.85$, blue including credible interval $(\mathrm{R}=0.85$, green square), exponential phase of decreasing return to the bottom (poor tolerance, R: $0.85-0.15$, yellow square), intolerance threshold including credible interval $(\mathrm{R}=0.15$, yellow square $)$ and range of intolerance $(\mathrm{R}$ : $0.15-0.00$, red square) shown for living and dead (control) specimens square), tolerance threshold

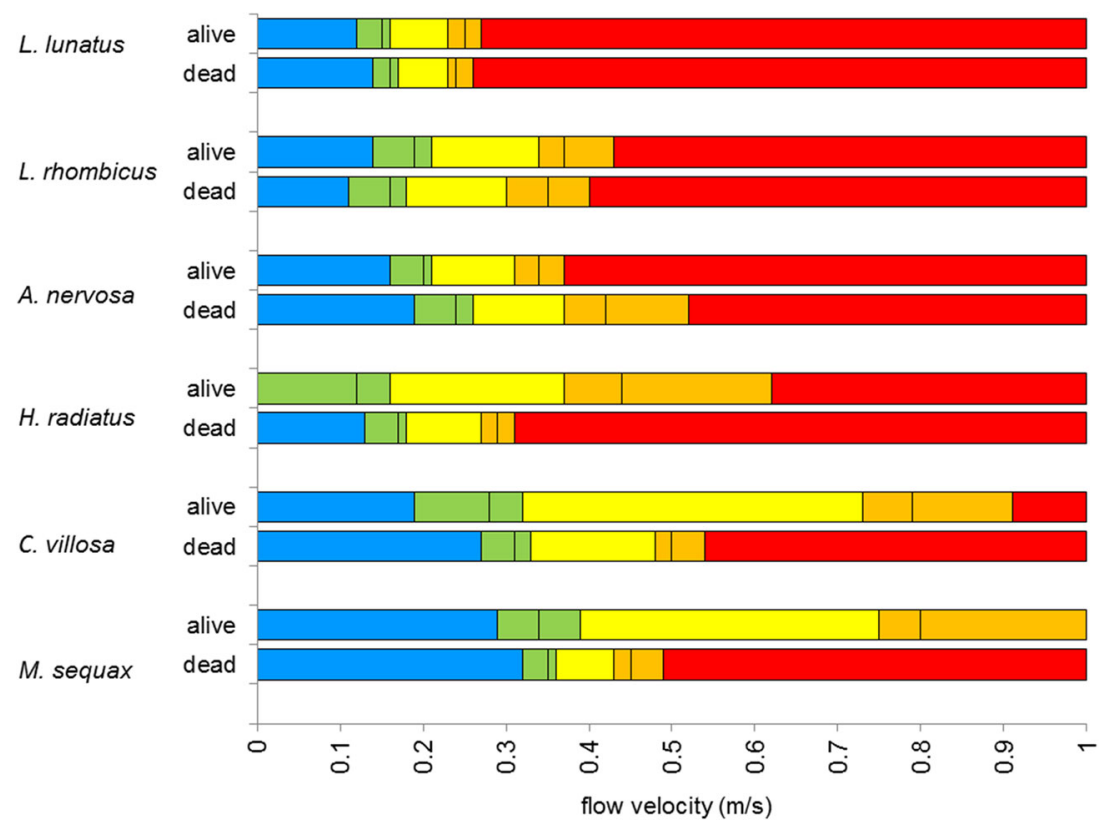

1991; Oldmeadow et al. 2010), the Trichoptera tested in this study showed no distinct swimming movements, but active behavioural movements like crawling and attaching were most beneficial for $H$. radiatus, $C$. villosa and $M$. sequax.

Average flow velocities in Dutch lowland streams are 0.2-0.3 m/s (Tolkamp 1980; Verdonschot 1995). We experimentally verified that $M$. sequax and $C$. villosa show return rate tolerances within this range, whereas the other four species showed lower tolerance limits. Especially, $L$. lunatus cannot return to the bottom from drift at $0.3 \mathrm{~m} / \mathrm{s}$ and will therefore need low flow areas. The role of low flow areas as refuges for drifting specimens to return to the bottom requires further research. Other studies have shown that refuges can reduce dislodgement probabilities of specimens and enable them to resist dislodgement despite relatively high shear stress (Lancaster and Hildrew 1993; Lancaster 1996; Gabel et al. 2008, 2012). The current observations show that flow velocities of $0.6 \mathrm{~m} / \mathrm{s}$, which are often reached during peak discharges in these lowland streams, are critical for all species. This means that once dislodged, the specimens cannot actively return to the bottom. Again, the role of refugia can be important as they can passively "catch" drifting specimens. Only M. sequax and C. villosa can tolerate velocities of $0.6 \mathrm{~m} / \mathrm{s}$, so management of lowland streams should try to prevent peak flows that exceed $0.6 \mathrm{~m} / \mathrm{s}$.

\section{Conclusions}

In this study we aimed to determine flow velocity thresholds for Limnephilidae to escape from drift and return to the bottom. We showed that the ability to return to the bottom from drift and the effect of behaviour on this process are species specific. Species on the lotic end of the gradient had higher return rates at high flow velocity treatments and used active behaviour more efficiently to return to the bottom from drift than those on the lentic end of the species gradient. We conclude that, in addition to dislodging resistance, the ability to settle from drift is of equal importance in determining flow velocity tolerance in lowland stream Trichoptera species.

Acknowledgments This work was supported by the Dutch Foundation for Applied Research of Water (STOWA). We are grateful to Cristina Alacreu Girón, David Argibay Aranda and Eva Serrano for their help collecting and monitoring the test specimens. Comments by an anonymous reviewer improved the paper.

Open Access This article is distributed under the terms of the Creative Commons Attribution 4.0 International License (http://crea tivecommons.org/licenses/by/4.0/), which permits unrestricted use, distribution, and reproduction in any medium, provided you give appropriate credit to the original author(s) and the source, provide a link to the Creative Commons license, and indicate if changes were made.

\section{References}

Allan JD, Johnson LB (1997) Catchment-scale analysis of aquatic ecosystems. Freshw Biol 37:107-111

Brittain JE, Eikeland TJ (1988) Invertebrate drift-a review. Hydrobiologia 166(1):77-93

Brosse S, Arbuckle CJ, Townsend CR (2003) Habitat scale and biodiversity: influence of catchment, stream reach and bedform scales on local invertebrate diversity. Biodivers Conserv 12:2057-2075

Ciborowski JJH, Pointing PJ, Corkum LD (1977) Effect of current velocity and sediment on drift of mayfly ephemerella-subvaria mcdunnough. Freshw Biol 7:567-572 
Conti L, Schmidt-Kloiber A, Grenouillet G, Graf W (2014) A traitbased approach to assess the vulnerability of European aquatic insects to climate change. Hydrobiologia 721:297-315

Corkum LD (1992) Spatial distributional patterns of macroinvertebrates along rivers within and among biomes. Hydrobiologia 239(2):101-114

Corkum LD, Pointing PJ, Ciborowski JJH (1977) influence of current velocity and substrate on distribution and drift of 2 species of mayflies (Ephemeroptera). Can J Zool Revue Canadienne De Zoologie 55:1970-1977

Dolédec S, Lamouroux N, Fuchs U, Mérigoux S (2007) Modelling the hydraulic preferences of benthic macroinvertebrates in small European streams. Freshw Biol 52:145-164

Downes BJ, Keough MJ (1998) Scaling of colonization processes in streams: parallels and lessons from marine hard substrata. Aust J Ecol 23:8-26

Feld CK, Hering D (2007) Community structure or function: effects of environmental stress on benthic macroinvertebrates at different spatial scales. Freshw Biol 52:1380-1399

Fonseca DM, Hart DD (1996) Density-dependent dispersal of black fly neonates is mediated by flow. Oikos 75:49-58

Gabel F, Garcia XF, Brauns M, Sukhodolov A, Leszinski M, Pusch MT (2008) Resistance to ship-induced waves of benthic invertebrates in various littoral habitats. Freshw Biol 53:1567-1578

Gabel F, Garcia XF, Schnauder I, Pusch MT (2012) Effects of shipinduced waves on litttoral benthic invertebrates. Freshw Biol 57:2425-2435

Gibbins CN, Scott E, Soulsby C, McEwan I (2005) The relationship between sediment mobilisation and the entry of Baetis mayflies into the water column in a laboratory flume. Hydrobiologia 533:115-122

Gibbins CN, Vericat D, Batalla RJ (2010) Relations between invertebrate drift and flow velocity in sand-bed and riffle habitats and the limits imposed by substrate stability and benthic density. J N Am Benthol Soc 29:945-958

Graf W, Schmidt-Kloiber A (2011) Additions to and update of the Trichoptera Indicator Database. www.freshwaterecology.info version 5.0

Graf W, J Murphy, J Dahl, C Zamora-Muñoz, MJ López-Rodríguez, A Schmidt-Kloiber (2006) Trichoptera Indicator Database. Eurolimpacs project, Workpackage 7-indicators of ecosystem health, Task 4, www.freshwaterecology.info version 5.0

Graf W, Murphy J, Dahl J, Zamora-Muñoz C, López-Rodríguez MJ (2008) Distribution and ecological preferences of European freshwater organisms, vol 1. Pensoft Publishers, Sofia-Moscow

Hart DD, Finelli CM (1999) Physical-biological coupling in streams: the pervasive effects of flow on benthic organisms. Annu Rev Ecol Syst 30:363-395

Hering D, Johnson RK, Kramm S, Schmutz S, Szoszkiewicz K, Verdonschot PFM (2006) Assessment of European streams with diatoms, macrophytes, macroinvertebrates and fish: a comparative metric-based analysis of organism response to stress. Freshw Biol 51:1757-1785

Hynes HBN (1970) Ecology of stream insects. Annu Rev Entomol $15: 25-42$

Lancaster J (1996) Scaling the effects of predation and disturbance in a patchy environment. Oecologia 107:321-331

Lancaster J (2008) Movement and dispersion of insects in stream channels: what role does flow play. Aquatic insects: challenges to populations. Wallingford, CABI, pp 139-157

Lancaster J, Hildrew AG (1993) Flow refugia and the microdistribution of lotic macroinvertebrates. J N Am Benthol Soc 12:385-393

Lancaster J, Downes BJ, Glaister A (2009) Interacting environmental gradients, trade-offs and reversals in the abundance-environment relationships of stream insects: when flow is unimportant. Mar Freshw Res 60:259-270

McLay C (1970) A theory concerning the distance travelled by animals entering the drift of a stream. J Fish Res Board Can 27:359-370

Mérigoux S, Dolédec S (2004) Hydraulic requirements of stream communities: a case study on invertebrates. Freshw Biol 49:600-613

Mérigoux S, Lamouroux N, Olivier JM, Dolédec S (2009) Invertebrate hydraulic preferences and predicted impacts of changes in discharge in a large river. Freshw Biol 54:1343-1356

Neves RJ (1979) Movements of larval and adult Pycnopsyche guttifer (Walker) (Trichoptera: limnephilidae) along Factory Brook, Massachusetts. Am Midl Nat 102:51-58

Oldmeadow DF, Lancaster J, Rice SP (2010) Drift and settlement of stream insects in a complex hydraulic environment. Freshw Biol 55:1020-1035

Ormerod SJ, Dobson M, Hildrew AG, Townsend CR (2010) Multiple stressors in freshwater ecosystems. Freshw Biol 55:1-4

Otto C (1976) Factors affecting drift of Potamophylax-Cingulatus (Trichoptera) Larvae. Oikos 27:93-100

Palmer MA, Arensburger P, Martin AP, Denman DW (1996) Disturbance and patch specific responses: the interactive effects of woody debris and floods on lotic invertebrates. Oecologia 105:247-257

Poff NL, Ward JV (1991) Drift responses of benthic invertebrates to experimental streamflow variation in a hydrologically stable stream. Can J Fish Aquat Sci 48:1926-1936

Rice SP, Lancaster J, Kemp P (2010) Experimentation at the interface of fluvial geomorphology, stream ecology and hydraulic engineering and the development of an effective, interdisciplinary river science. Earth Surface Processes Landf 35:64-77

Sagnes P, Mérigoux S, Peru N (2008) Hydraulic habitat use with respect to body size of aquatic insect larvae: case of six species from a French Mediterranean type stream. Limnologica 38:23-33

Schnauder I, S Rudnick, XF Garcia, J Aberle (2010) Incipient motion and drift of benthic invertebrates in boundary shear layers. In: Dittrich A, Koll K, Aberle J, Geisenhainer P (eds) River flow 2010. Proceedings of 5th International Conference on Fluvial Hydraulics, September 7-10, Braunschweig, Germany

Statzner B, Gore JA, Resh VH (1988) Hydraulic stream ecologyobserved patterns and potential applications. J N Am Benthol Soc 7:307-360

Tolkamp HH (1980) Organism-substrate relationships in lowland streams. Dissertation, Wageningen University, Wageningen

Verdonschot PFM (1995) Typology of macrofaunal assemblages-a tool for the management of running waters in the Netherlands. Hydrobiologia 297:99-122

Verdonschot PFM, Besse-Lototskaya AA, Dekkers DBM, Verdonschot RCM (2012) Mobility of lowland stream Trichoptera under experimental habitat and flow conditions. Limnologica 42:227-234

Verdonschot PFM, Besse-Lototskaya AA, Dekkers TBM, Verdonschot RCM (2014) Directional movement in response to altered flow in six lowland stream Trichoptera. Hydrobiologia 740(1):219-230

Vogel S (1994) Life in moving fluids: the physical biology of flow. Princeton University Press, Princeton

Waringer JA (1989) Resistance of a cased caddis larva to accidental entry into the drift: the contribution of active and passive elements. Freshw Biol 21:411-420

Waringer J, Graf W (2011) Atlas of Central European Trichoptera Larvae. Erik Mauch Verlag, Dinkelscherben

Waters TF (1972) The drift of stream insects. Annu Rev Entomol $17: 253-272$

Weigel BM (2003) Development of stream macroinvertebrate models that predict watershed and local stressors in Wisconsin. J N Am Benthol Soc 22:123-142 